The 25th Lung Cancer Mass Screening Seminar

\title{
肺癌検診の予後調査の必要性と問題点 一がん登録の利用
}

\author{
早田＼cjkstart宏 1 富田弘志 2 ・早田みどり 3 ・河野＼cjkstart茂 4
}

\section{Necessity of and Problems in Survival Investigation for Lung Cancer Screening - Linkage to a Cancer Registry-}

\author{
Hiroshi Soda1; Hiroshi Tomita2; Midori Soda3; Shigeru Kohno 4 \\ ${ }^{1}$ Division of Respiratory Medicine, Sasebo City General Hospital, Japan; ${ }^{2}$ Nagasaki Prefecture Medical Health Operation Group, \\ Japan; ${ }^{3}$ Nagasaki Prefecture Cancer Registry, Radiation Effects Research Foundation, Japan; ${ }^{4}$ Second Department of Internal \\ Medicine, Nagasaki University School of Medicine, Japan.
}

\begin{abstract}
Objective. This study was designed to investigate whether the efficacy of population-based screening of lung cancer may vary according to gender and histological type. Methods. Records of lung cancer screening using chest radiography were compared to the data of the Nagasaki Cancer Registry. Sensitivity of the screening, retrospective evidence of cancers on previous radiographs, and 10-year survival rates of patients were evaluated. Results. The sensitivity and 10 -year survival rates were 0.85 and $26.7 \%$ for adenocarcinoma (AD), and 0.52 and $5.0 \%$ for squamous cell carcinoma (SQ), respectively. The difference in 10-year survival rates was small between screening-detected and interval-detected patients with SQ. Most female AD patients had retrospective evidence of cancer on radiographs for 2 and 3 years before detection, and male AD patients had retrospective evidence of cancer for 1 and 2 years before detection. In contrast, most SQ cases showed no evidence of cancer on radiographs taken 1 year before detection, suggesting that SQ developed rapidly, and that AD, especially female AD, grew slowly. Ten-year survival rates of patients between the screened population and the general population of Nagasaki Prefecture were $31.8 \%$ vs. $22.3 \%$ for female non-small cell lung cancer, $16.6 \%$ vs. $13.9 \%$ for male nonsmall cell lung cancer patients, $36.3 \%$ vs. $24.1 \%$ for female AD patients, $22.4 \%$ vs. $14.7 \%$ for male AD patients, and $5.7 \%$ vs. $13.4 \%$ for SQ patients, respectively. Conclusions. Our findings suggest that the efficacy of radiologic screening for lung cancer may be higher in female $\mathrm{AD}$ patients followed by male AD patients and SQ patients. When the effectiveness of lung cancer screening is discussed based on the results from the studies of various target population, more attention should be paid to the difference in the distributions of gender and histological type.
\end{abstract}

KEY WORDS — L Lung cancer screening, Lung cancer registry, Survival analysis

(JJLC. 2012;52:961-967)

Reprints: Hiroshi Soda, Division of Respiratory Medicine, Sasebo City General Hospital, 9-3 Hirase-cho, Sasebo-shi, Nagasaki 857-8511, Japan (e-mail: h-souda@hospital.sasebo.nagasaki.jp).

要旨一一目的. 肺癌住民検診の効果が性・組織型別に 異なるか，検討を行った．方法．胸部 X 線を用いた肺癌 検診のデー夕を長崎県がん登録のデータと照合し，検診 の感度, 過去フィルムでの肺癌陰影の有無, 肺癌患者の 10 年生存率を評価した. 結果. 肺癌検診の感度は腺癌で 0.85 , 扁平上皮癌で 0.52 であった. 10 年生存率は腺癌で
$26.7 \%$, 扁平上皮癌で $5.0 \%$ であった. 扁平上皮癌では検 診発見と検診外発見の 10 年生存率の差は小さかった. 女 性腺癌のほとんどは検診発見 $2 \sim 3$ 年前に, 男性腺癌は検 診発見前 $1 \sim 2$ 年前に肺癌陰影が出現した. 一方, 扁平上 皮癌は検診発見 1 年以内の出現がほとんどであった．扁 平上皮癌は発育の早い癌であり, 腺癌, 特に女性腺癌は
1佐世保市立総合病院呼吸器内科 ; 2長崎県健康事業団 ; 3放射線 影響研究所長崎県がん登録室；4長崎大学医学部第二内科.

別刷請求先：早田 宏, 佐世保市立総合病院呼吸器内科, $=857$ -
8511 長崎県佐世保市平瀬町 9 番 3 号 (e-mail: h-souda@hospital. sasebo.nagasaki.jp). 
発育が緩徐な癌であることが示唆された. 10 年生存率 （検診集団 vs. 長崎県一般集団）は，女性非小細胞癌 (31.8\% vs. $22.3 \%)$, 男性非小細胞癌 (16.6\% vs. $13.9 \%)$, 女性腺癌 (36.3\% vs. $24.1 \%$ ), 男性腺癌 (22.4\% vs. $14.7 \%)$, 扁平上皮癌 ( $5.7 \%$ vs. $13.4 \%)$ であった. 結語. 今回の結果より, 肺癌 X 線検診の効果は女性腺癌, 男性
腺癌, 扁平上皮癌の順で低下する可能性が示唆された. 様々な対象集団の研究の結果から肺癌検診の有効性を論 じる場合には，その集団内の性・組織型の構成の違いに 注意をより払うべきと考えられる。

索引用語 一一肺癌検診, 肺癌登録, 生存解析

\section{はじめに}

肺癌検診の有効性については, ランダム化比較試験で 死亡率を減少させることが証明できなかったため, 12 欧 米では健康施策として推奨されていない。一方, 我が国 の胸部 X 線写真を主とする肺癌検診は, 症例対照研究か ら検診受診集団の肺癌死亡率を減少させる効果が示唆さ れている. 3-5

肺癌は異なる組織型から構成されることや EGF（epidermal growth factor) 受容体遺伝子変異が東アジア人に 多いことなど，多様性がある腫瘍である，肺癌検診の効 果を評価する場合には，この多様性を考慮しなければ， 異なる結果が得られる可能性がある。我々は肺癌検診の 感度や肺癌の発育の早さが組織型で異なることを報告し てきた. 6 今回，地域がん登録デー夕を利用して，検診受 診者の 10 年生存率を検討し, 肺癌検診の効果が性・組織 型で異なる可能性があることを報告する。

\section{方 法}

\section{Study 1}

1987 1988 年の長崎県内で実施された胸部 X 線住民 検診の受診者を対象とした。検診方法は, 40 歳以上の男 女で間接撮影の二重読影と比較読影を行った。長崎県が ん登録との照合により，検診受診 1 年以内の検診外発見 肺癌を把握し, 検診の感度を性・組織型別に評価した。

\section{Study 2}

1997〜2000 年の長崎県内で実施された胸部住民検診 の受診者を対象とした．検診方法は，40歳以上の男女で 間接撮影の二重読影と比較読影を行い，喫煙指数 600 以 上で喀痰細胞診の併用を行った，検診の効果は，1986〜 1995 年の 10 年間に長崎県がん登録に新規登録された原 発性肺癌症例より, 性・年齢・組織型別の肺癌罹患率を 求め, 検診受診集団中の肺癌症例の期待值を計算し，発 見值との比較を行った。

\section{Study 3}

検診集団の 40～79 歳の肺癌症例（1987～1988 年）と長 崎県一般集団の 40～79 歳の肺癌症例（1986１994 年） の, 10 年生存率を性・組織型別に評価した。

\section{統計解析}

二群間の比較は Bonferroni 法を用いた Fisher 直接確 率検定で行い, 生存曲線は Kaplan-Meier 推定法を用い た.

\section{結 果}

\section{1. 組織型別にみた検診の感度}

1987 1988 年の胸部住民検診受診者のべ 205,401 人 （男性 75,381 人，女性 130,020 人）加, 肺癌 140 人（男 性 96 人，女性 44 人) が胸部 X 線にて発見されたＩ期は 73 人（男性 48 人，女性 25 人）であった。 しかし，がん 登録との照合で検診を受けたにもかかわらず検診外で肺 癌 59 人が発見され, 胸部 X 線検診の感度は $140 / 199$ (0.70，95\% 信頼区間 0.63 0.77) であった (Table 1). 感 度は男性肺癌 0.68 , 女性肺癌 0.77 , 腺癌 0.85 , 扁平上皮癌 0.52 であった，扁平上皮癌は腺癌よりも感度が低かった $(\mathrm{P}<0.001)$.

1997 2000 年の胸部検診受診者はのべ 354,974 人（男 性 123,298 人，女性 231,676 人）であった．検診にて肺癌 326 人（男性 216 人，女性 110 人）が発見された. I 期は 155 人（男性 94 人, 女性 61 人) であった. 発見方法は, 胸部 X 線のみの発見が 296 人, 喀痰細胞診のみの発見が 8 人，両者によるものが 22 人であった.

長崎県がん登録では 1986 1995 年の 10 年間で男性肺 癌 5,668 人, 女性肺癌 2,309 人が登録された。組織型判明 率は 0 79 歳で $78 \% ， 80$ 歳以上で $42 \%$ であった．肺癌 の組織型の内訳をみると, 男性は腺癌 $40.7 \%$, 扁平上皮癌 $36.7 \%$ と腺癌がやや多く, 女性では, 腺癌 $72.2 \%$, 扁平上 皮癌 $13.7 \%$ と，多くが腺癌であった。

長崎県がん登録（1986１995 年）による性・年齢・組 織型別罹患率 (Figure 1) からの検診集団中の期待值と検 診（1997〜2000 年）の発見数とを比較した. 組織型別の 発見比は組織型不明例の影響を受けて実際よりも高くで る可能性があるものの, 全体の発見比は $0.63(95 \%$ 信頼 区間 $0.59 \sim 0.67$ ) であった (Table 2). 発見比の内訳は, 男性肺癌 0.59, 女性肺癌 0.72 , 腺癌 1.03 , 扁平上皮癌 0.64 であった，発見比は女性が男性よりも高く $(\mathrm{P}<0.01)$ ，腺 癌が扁平上皮癌よりも高かった $(\mathrm{P}<0.001)$. 
Table 1. Sensitivity of Radiologic Lung Cancer Screening According to Gender and Histological Type in Nagasaki, 1987-1988*

\begin{tabular}{lccc}
\hline & $\begin{array}{c}\text { Screening-detected cases/ } \\
\text { All cases }\end{array}$ & Sensitivity & $\begin{array}{c}95 \% \text { confidence } \\
\text { interval }\end{array}$ \\
\hline $\begin{array}{l}\text { Gender } \\
\quad \text { Male }\end{array}$ & $96 / 142$ & 0.68 & $0.59-0.75$ \\
$\quad$ Female & $44 / 57$ & 0.77 & $0.64-0.87$ \\
& & & \\
Histological type & $91 / 107$ & 0.85 & $0.77-0.91$ \\
$\quad$ Adenocarcinoma ${ }^{\dagger}$ & $26 / 50$ & 0.52 & $0.37-0.66$ \\
$\quad$ Squamous cell & $12 / 24$ & 0.50 & $0.29-0.71$ \\
$\quad$ Small cell & $11 / 18$ & 0.61 & $0.36-0.83$ \\
$\quad$ Others & & & \\
& $140 / 199$ & 0.70 & $0.63-0.77$ \\
\hline
\end{tabular}

*The sensitivity was defined as (number of screening-detected cases)/(total number of lung cancers arising in the study population). P-values were determined by Fisher's exact test using the Bonferroni method.

${ }^{\dagger} \mathrm{P}<0.001$ compared with squamous cell carcinoma and small cell carcinoma.
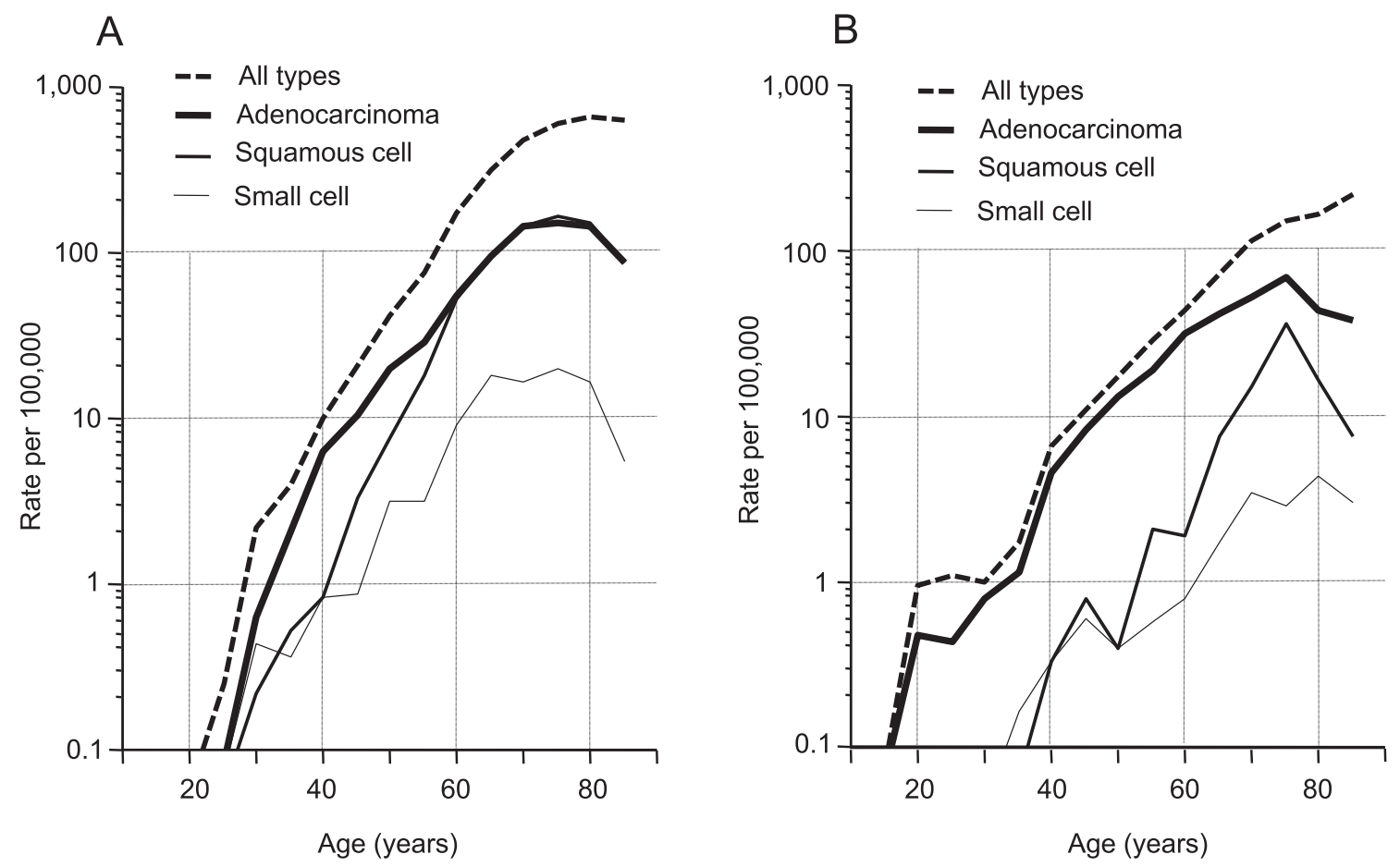

Figure 1. Age-specific incidence of lung cancers for males (A) and females (B) in Nagasaki, 1986-1995, according to histological type.

\section{2. 組織型別にみた検診集団の 10 年生存率}

検診集団（1987〜 1988 年）の肺癌の 10 年生存率は 16.6\%（男性 $13.3 \% ， 女$ 女性 $27.4 \%$ ）であった。組織型別の 10 年生存率（検診発見 vs. 検診外発見）は，腺癌 $26.7 \%$ (31.4\% vs. 0\%), 扁平上皮癌 5.0\% (7.7\% vs. 0\%) で，扁 平上皮癌の発見契機による生存率の差は小さかった
(Figure 2).

扁平上皮癌は腺癌と比較して検診の感度は低く（P< $0.0001)$, 発見 1 年前の肺癌陰影の存在も扁平上皮癌で低 $<(\mathrm{P}<0.0001)$, 扁平上皮癌は発育の早いことが示唆され た (Table 3$)$. 
Table 2. Detection Ratio of Lung Cancer Screening Using Chest Radiography and Sputum Cytology According to Gender and Histological Type in Nagasaki, 1997-2000*

\begin{tabular}{|c|c|c|c|}
\hline & $\begin{array}{l}\text { Screening-detected cases/ } \\
\text { Expected cases }\end{array}$ & Detection ratio & $\begin{array}{l}95 \% \text { confidence } \\
\text { interval }\end{array}$ \\
\hline \multicolumn{4}{|l|}{ Gender } \\
\hline Male & $216 / 368$ & 0.59 & $0.53-0.64$ \\
\hline Female $^{\dagger}$ & $110 / 152$ & 0.72 & $0.65-0.79$ \\
\hline \multicolumn{4}{|l|}{ Histological type } \\
\hline Adenocarcinoma & $185 / 180$ & 1.03 & $1.00-1.04$ \\
\hline Squamous cell & $77 / 121$ & 0.64 & $0.54-0.72$ \\
\hline Small cell & $21 / 47$ & 0.45 & $0.30-0.60$ \\
\hline Others \& Unknown & $43 / 172$ & 0.25 & $0.19-0.32$ \\
\hline Overall & $326 / 520$ & 0.63 & $0.59-0.67$ \\
\hline
\end{tabular}

* Number of expected cases in the study population was calculated by using the agespecific incidence in Nagasaki, 1986-1995, and the detection ratio was defined as (number of screening-detected cases)/(number of expected cases). P-values were determined by Fisher's exact test using the Bonferroni method.

${ }^{\dagger} \mathrm{P}<0.01$ compared with male.

${ }^{\ddagger} \mathrm{P}<0.001$ compared with squamous cell carcinoma and small cell carcinoma.

A

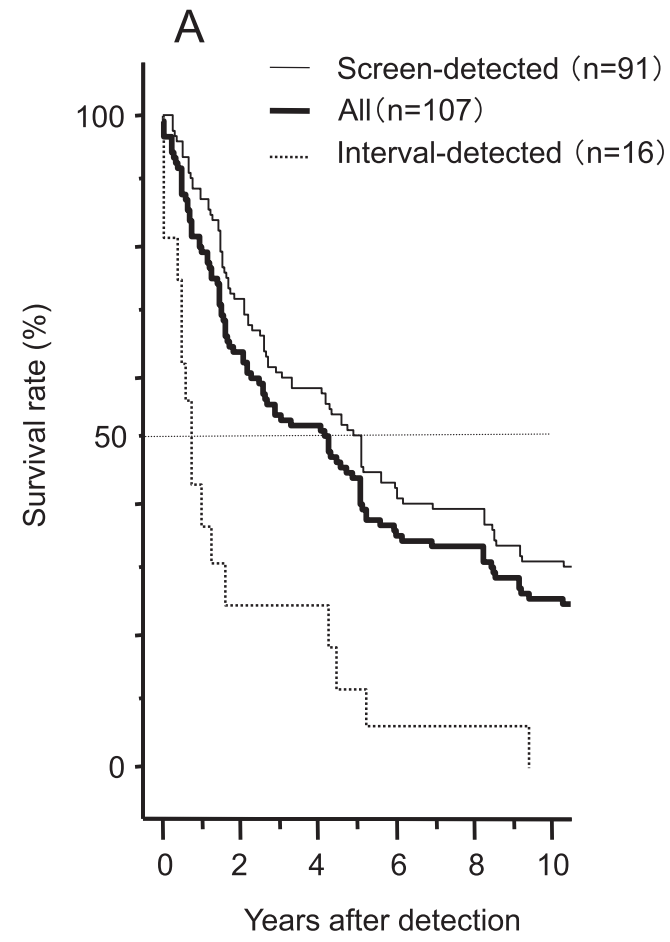

B

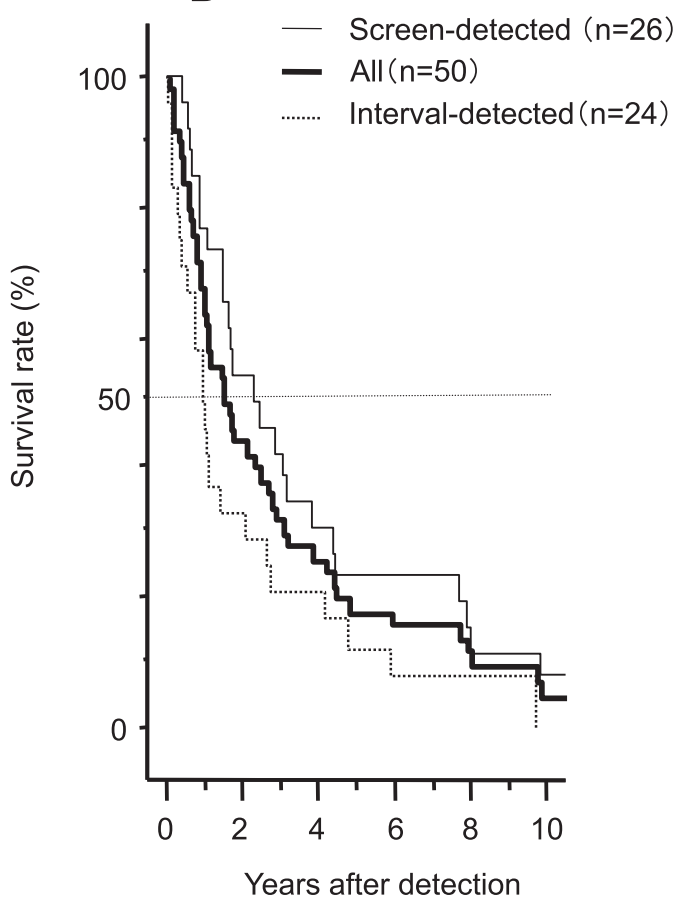

Figure 2. Kaplan-Meier estimates of survival of patients with adenocarcinoma (A) and squamous cell carcinoma (B) in Nagasaki, 1987-1988, according to method of detection. In adenocarcinoma patients, 10-year survival rates and median survival time were $26.7 \%$ and 4.3 years for all cases, $31.4 \%$ and 5.1 years for screen-detected cases, and $0 \%$ and 0.8 year for interval-detected cases, respectively. In squamous cell carcinoma patints, 10-year survival rates and median survival time were $5.0 \%$ and 1.5 years for all cases, $7.7 \%$ and 2.3 years for screen-detected cases, and $0 \%$ and 1.0 year for interval-detected cases, respectively. The bars showing censored cases were omitted. 
Table 3. Characteristics of Non-small Cell Lung Cancer According to Histological Type in Nagasaki, 1987-1988*

\begin{tabular}{lccc}
\hline & Adenocarcinoma & Squamous cell & P-value \\
\hline Sensitivity of radiologic screening & $91 / 107(85 \%)$ & $26 / 50(52 \%)$ & $\mathrm{P}<0.0001$ \\
& & & \\
$\begin{array}{l}\text { Proportion of stage I disease among screening- } \\
\text { detected cases and interval cases }\end{array}$ & $55 / 107(51 \%)$ & $18 / 50(36 \%)$ & N.S.
\end{tabular}

Retrospective evidence of cancer on previous films, time for detection ${ }^{\dagger}$

\begin{tabular}{lrcc} 
1-year-old films & $62 / 81(77 \%)$ & $16 / 50(32 \%)$ & $\mathrm{P}<0.0001$ \\
2-year-old films & $36 / 68(53 \%)$ & $1 / 21(5 \%)$ & $\mathrm{P}<0.001$ \\
3-year-old films & $8 / 47(17 \%)$ & $0 / 20(0 \%)$ & N.S. \\
\hline
\end{tabular}

*P-values were determined by Fisher's exact test using the Bonferroni method.

${ }^{\dagger}$ Retrospective evidence of cancer on previous films was calculated as (number with evidence)/ (number of reviewed films).

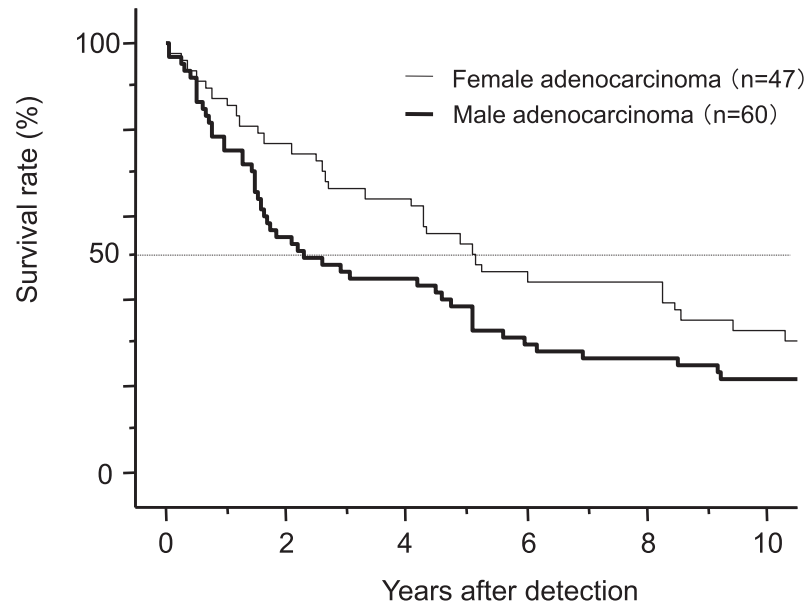

Figure 3. Kaplan-Meier estimates of survival of patients with adenocarcinoma in Nagasaki, 1987-1988, according to gender. Ten-year survival rates and median survival time were $33.2 \%$ and 5.2 years for female adenocarcinoma, and $21.7 \%$ and 2.3 years for male adenocarcinoma, respectively. The bars showing censored cases were omitted.

\section{3. 検診集団の腺癌の 10 年生存率の性差}

検診集団 (1987〜 1988 年) の腺癌の 10 年生存率は男性 腺癌 $21.7 \%$ ，女性腺癌 $33.2 \%$ であった (Figure 3)，男性 腺癌と女性腺癌は感度や I 期の割合に有意差はなかった が, 発見 2 年前の検診時の肺癌㓌影の存在は男性腺癌で 低く $(\mathrm{P}<0.0001)$, 男性腺癌は女性肺癌よりも発育がやや 早いことが示唆された（Table 4).

\section{4. 非切除 I 期肺癌の生存曲線}

肺癌の自然史を評価するために，長崎県がん登録 （1986１994 年）から長崎県一般集団での I 期肺癌非切 除例の生存曲線を検討した (Figure 4). 非切除に至った
背景因子を考慮しなければならないが，非切除 I 期例で は, 女性腺癌, 男性腺癌, 扁平上皮癌のいずれも 10 年生 存率は $0 \%$ で, 生存期間中央值は $1.0 \sim 1.4$ 年であった. な お， 切除 I 期例の 10 年生存率は女性腺癌（61.9\%）が最 も良好で, 次いで男性腺癌 (48.0\%), 扁平上皮癌 (34.8\%) であった。

\section{5. 検診集団と一般集団の肺癌の 10 年生存率}

1987〜1988 年の検診集団中の非小細胞肺癌（40～79 歳) と 1986〜1994 年のがん登録された長崎県一般集団の 非小細胞肺癌（40～79 歳）の生存率の比較を行った. 検 診集団では lead-time bias や self-selection biasを，一般 集団では検診・医療機関での発見例が含まれる contamination を考慮しなければならない. 10 年生存率 (検 診集団 vs. 一般集団）は，男性非小細胞癌（16.6\% vs.

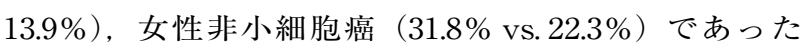
(Figure 5). 性・組織型別に 10 年生存率(検診集団 vs. 一般集団）をみると（Figure 6)，男性腺癌（22.4\% vs. $14.7 \%$ ), 女性腺癌 ( $36.3 \%$ vs. $24.1 \%$ ), 扁平上皮癌 (5.7\% vs. $13.4 \%$ ) であった.

\section{考 察}

今回の結果は, 性・組織型によって肺癌の発育の速さ, 検診の感度, 10 年生存率が異なっており, 肺癌検診の効 果が一様でないことを示していた.

検診の効果は死亡率の低下を証明することが必要であ る. 生存率は様々な bias が混じることから, 生存率を もって検診の効果を評価することは適切ではないとされ るが, 死亡率の低下のためには良好な生存率が前提条件 である.ただし, 生存解析で lead-time bias の影響を受け ない追跡期間の長さは明らかではない. 肺癌の sojourn time (asymptomatic detectable period) は平均 $1 \sim 4$ 年と 
Table 4. Characteristics of Adenocarcinoma According to Gender in Nagasaki, Japan, 1987-1988*

\begin{tabular}{|c|c|c|c|}
\hline & $\begin{array}{c}\text { Male } \\
\text { adenocarcinoma }\end{array}$ & $\begin{array}{c}\text { Female } \\
\text { adenocarcinoma }\end{array}$ & P-value \\
\hline Sensitivity of radiologic screening & $52 / 60(87 \%)$ & $39 / 47(83 \%)$ & N.S. \\
\hline $\begin{array}{l}\text { Proportion of stage I disease among screening- } \\
\text { detected cases and interval cases }\end{array}$ & $29 / 60(48 \%)$ & $26 / 47(55 \%)$ & N.S. \\
\hline \multicolumn{4}{|l|}{$\begin{array}{l}\text { Retrospective evidence of cancer on previous } \\
\text { films, time for detection }{ }^{\dagger}\end{array}$} \\
\hline 1-year-old films & $34 / 46(74 \%)$ & $28 / 35(80 \%)$ & N.S. \\
\hline 2-year-old films & $11 / 37(30 \%)$ & 25/31 (81\%) & $\mathrm{P}<0.0001$ \\
\hline 3-year-old films & 4/31 (13\%) & $4 / 16(25 \%)$ & N.S. \\
\hline
\end{tabular}

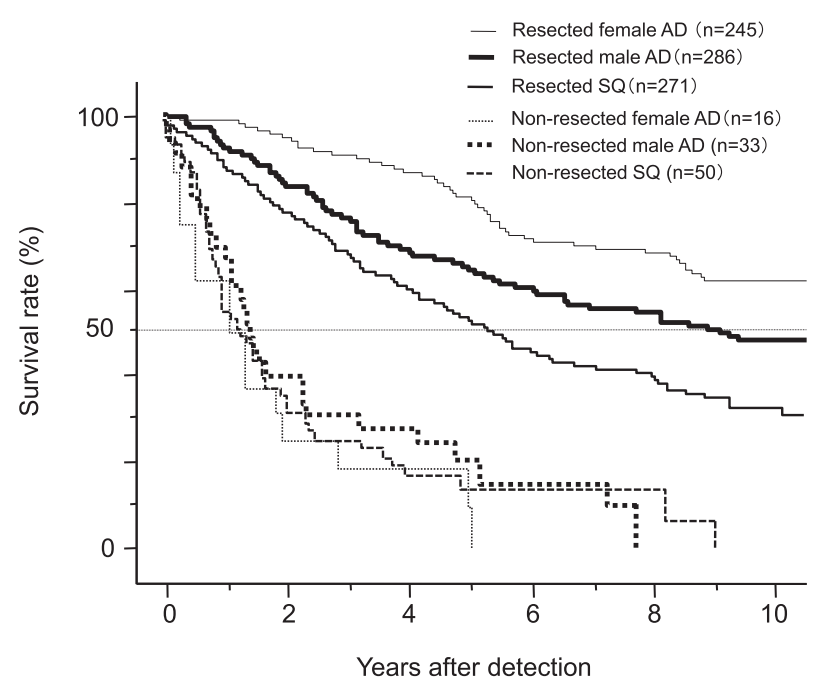

Figure 4. Kaplan-Meier estimates of survival of patients with stage I adenocarcinoma (AD) and squamous cell carcinoma (SQ) aged 40-79 years old, comparing resected cases with non-resected cases in Nagasaki, 1986-1994. Tenyear survival rates and median survival time were $61.9 \%$ and did not reach the value for resected female with $\mathrm{AD}$, $48.0 \%$ and 9.1 years for resected male $\mathrm{AD}$, and $34.8 \%$ and 5.6 years for resected SQ patients, respectively. In contrast, 10-year survival rates and median survival time were $0 \%$ and 1.0 year for non-resected female $\mathrm{AD}, 0 \%$ and 1.4 years for non-resected male $\mathrm{AD}$, and $0 \%$ and 1.3 years for non-resected SQ, respectively. The bars showing censored cases were omitted.

推定されている. ${ }^{3}$ 今回の検討では, 非切除 $\mathrm{I}$ 期例の生存 期間中央值は $1.0 \sim 1.4$ 年で, 過去の報告でも非切除 I 期 例の生存期間中央值は 13〜25 力と類似の結果が得ら れている. 7 緩やかな発育をする女性腺癌でも検診発見 2〜3 年前にほとんどが出現しており (Table 4), 平均 1〜

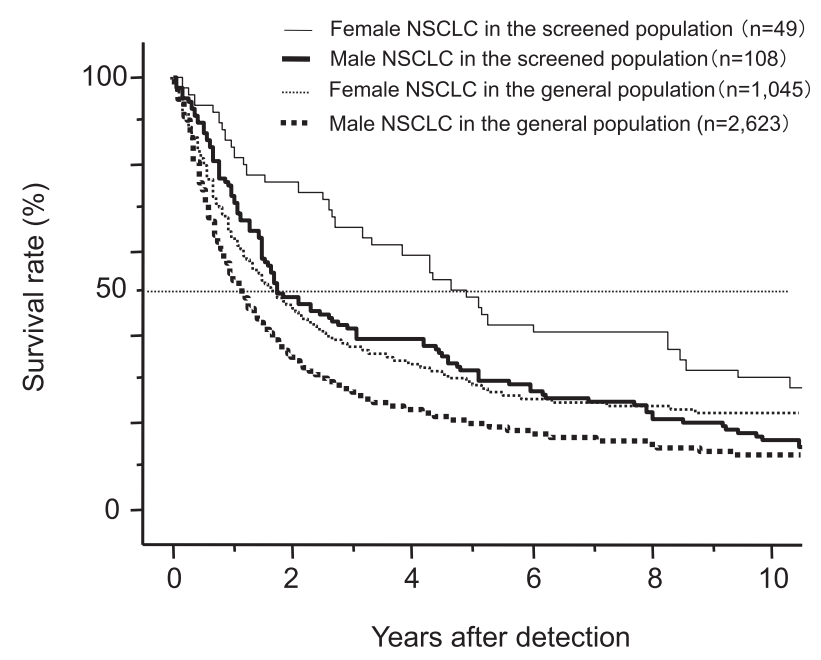

Figure 5. Kaplan-Meier estimates of survival of patients with non-small cell lung cancer (NSCLC) aged 40-79 years old, comparing those in the screened population (1987-1988) with those in the general population of Nagasaki Prefecture (1986-1994). Ten-year survival rates and median survival time for female NSCLC were $31.8 \%$ and 5.1 years in the screened population, and $22.3 \%$ and 1.8 years in the general population, respectively. In contrast, 10-year survival rates and median survival time for male NSCLC were $16.6 \%$ and 1.8 years in the screened population, and $13.9 \%$ and 1.2 years in the general population, respectively. The bars showing censored cases were omitted.

4 年の sojourn time の期間は妥当と考えられる.よって, 10 年生存率は lead-time bias の影響が全くないとは言え ないものの, その影響を小さくして評価できる方法とは 考えられる.

今回の時期・方法の異なる 2 つの感度の検討（Table 1, 2) からは, 胸部 X 線検診を主とする肺癌検診の感度 は約 60〜 70\% であり, 扁平上皮癌の感度は約 50〜 60\% 


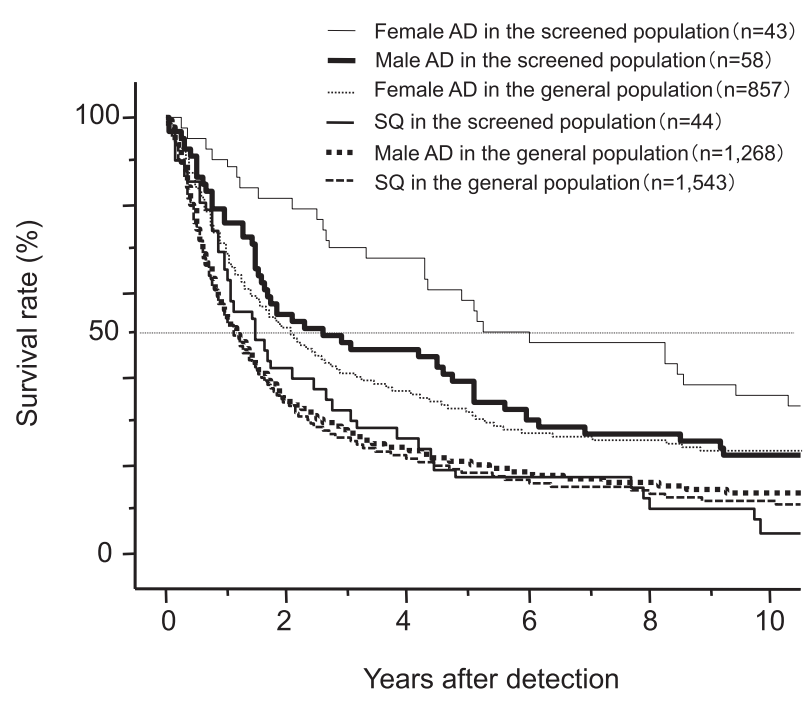

Figure 6. Kaplan-Meier estimates of survival of patients with adenocarcinoma (AD) and squamous cell carcinoma (SQ) aged 40-79 years old, comparing those in the screened population (1987-1988) with those in the general population of Nagasaki Prefecture (1986-1994). 10-year survival rates and median survival time for female AD were $36.3 \%$ and 6.0 years in the screened population, and $24.1 \%$ and 2.2 years in the general population, respectively. In contrast, 10-year survival rates and median survival time for male $\mathrm{AD}$ were $22.4 \%$ and 2.6 years in the screened population, and $14.7 \%$ and 1.2 years in the general population, respectively. Furthermore, 10-year survival rates and median survival time for SQ were $5.7 \%$ and 1.5 years in the screened population, and $13.4 \%$ and 1.2 years in the general population, respectively. The bars showing censored cases were omitted.

と低く，腺癌は約 80〜 100\% と高いことが示された。 ま た, 生存曲線でみると, 扁平上皮癌では検診外発見と検 診発見の差が小さく(Figure 2), 検診集団と一般集団と の生存の差も乏しかった (Figure 6). 扁平上皮癌は検診 の感度および生存曲線から肺癌検診の効果はそしいと考 えられた。

男性腺癌と女性腺癌では, 検診の感度や I 期の割合に 差はないものの, 生存曲線 (Figure 6) では検診集団の女 性腺癌が他のいずれの集団よりも生存が最も良好であっ た. また, 治癒が期待できる I 期切除例でも女性腺癌の生 存が最も良好であった (Figure 4). 高い検診の感度と良
好な 10 年生存率から, 女性腺癌は, 男性肺癌よりも検診 に適している可能性がある.

今回の検討より, 肺癌検診の有効性を比較して論ずる 場合には, その集団内の性, 組織型の分布などの背景因 子の異同が重要である。また, 地域がん登録は, 我が国 の肺癌の全体像を明らかにするために重要なデータベー スであり, がん登録との照合により地域での肺癌検診の 精度管理がなされることが重要である.

\section{結 語}

胸部 X 線検診を主とする肺癌検診の効果は女性腺癌, 男性腺癌, 扁平上皮癌の順に低下する可能性が示唆され た. 肺癌検診の有効性を異なる集団で比較する場合には, その集団内の性別, 組織型などの背景因子の異同に注意 を払うべきである。

本論文内容に関連する著者の利益相反：なし

\section{REFERENCES}

1. Fontana RS, Sanderson DR, Woolner LB, Taylor WF, Miller WE, Muhm JR, et al. Screening for lung cancer. A critique of the Mayo Lung Project. Cancer. 1991;67 (Suppl):1155-1164.

2. Oken MM, Hocking WG, Kvale PA, Andriole GL, Buys SS, Church TR, et al. Screening by chest radiograph and lung cancer mortality: the Prostate, Lung, Colorectal, and Ovarian (PLCO) randomized trial. JAMA. 2011;306: 1865-1873.

3. Sagawa M, Nakayama T, Tsukada H, Nishii K, Baba T, Kurita Y, et al. The efficacy of lung cancer screening conducted in 1990s: four case-control studies in Japan. Lung Cancer. 2003;41:29-36.

4. 厚生労働省がん研究助成金「がん検診の適切な方法とそ の評価法の確立に関する研究」班. 有効性評価に基づく肺 がん検診ガイドライン. 東京 : 厚生労働省 ; 2006.

5. 日本肺癌学会. EBM の手法による肺癌診療ガイドライン 2010 年度版. 肺癌集団検診ガイドライン. http://www. haigan.gr.jp/modules/guideline/index.php?content_id= 3 (Accessed on 11.26.2010)

6. Soda H, Tomita H, Kohno S, Oka M. Limitation of annual screening chest radiography for the diagnosis of lung cancer. A retrospective study. Cancer. 1993;72:2341-2346.

7. Sobue T, Suzuki T, Matsuda M, Kuroishi T, Ikeda S, Naruke T. Survival for clinical stage I lung cancer not surgically treated. Comparison between screen-detected and symptom-detected cases. The Japanese Lung Cancer Screening Research Group. Cancer. 1992;69:685-692. 